\title{
Highly Diastereoselective Cascade [5+1] Double Michael Reaction, a Route for The Synthesis of Spiro Thio-Oxindoles
}

Firouz Matloubi Moghaddam ( $\nabla$ matloubi@sharif.edu )

Sharif University of Technology

Vahid Saberi

Sharif University of Technology

Ashkan Karimi

McGill University

\section{Research Article}

Keywords: Spiro-thiooxindole, Michael addition, Diastereoselective

Posted Date: September 23rd, 2021

DOI: https://doi.org/10.21203/rs.3.rs-898551/v1

License: (c) (1) This work is licensed under a Creative Commons Attribution 4.0 International License.

Read Full License

Version of Record: A version of this preprint was published at Scientific Reports on November 24th, 2021. See the published version at https://doi.org/10.1038/s41598-021-01766-6. 


\title{
Highly Diastereoselective Cascade [5+1] Double Michael Reaction, a Route for the Synthesis of Spiro Thio-oxindoles
}

\author{
Firouz Matloubi Moghaddam*, Vahid Saberia, Ashkan Karimia,b \\ a Laboratory of Organic Synthesis and Natural Products, Department of Chemistry, \\ Sharif University of Technology, 111559516 Tehran, Iran \\ b Department of Chemistry, McGill University, H3A-0B8 Montreal, Canada \\ E-mail Address: matloubi@sharif.edu
}

\begin{abstract}
The first diastereoselective synthesis of spiro-thiooxindole is reported via Michael reaction between thiooxindoles and divinyl ketones. The reaction was conducted without any catalyst or additive under green conditions, i.e., ethanol as the solvent and room temperature. This study showed the art of governing regioselectivity in which novel spiro frameworks were generated in high yields. In addition to simple and column chromatography-free purification, the high diastereoselectivity makes this protocol very robust. The regio- and stereo- selectivity of the reaction has been discussed in light of the theoretical calculations, and molecular docking has been performed on the reaction products. Our method presents the first synthesis of cis-spiro thiooxindoles, which can be used to generate cis-spiro oxindoles. According to our docking studies, the latter demonstrates higher binding affinities towards the LdUMPS than corresponding trans-spiro oxindoles and may be utilized to develop new hit compounds for leishmaniasis treatment.
\end{abstract}

Keywords: Spiro-thiooxindole, Michael addition,

Diastereoselective

\section{Introduction}

Oxindole scaffolds have been found as a vital pharmacophore, ${ }^{1}$ encountered in natural products ${ }^{2,3}$ and pharmaceutical compounds. Inspired by the presence of spiro oxindole in several natural products such as gelsemine, chitosenine, spirotryprostatin B, and NITD609 4-11 (Figure 1), it is known that introducing a tetrahedral spiro carbon can further improve bioactivity by providing structural rigidity. ${ }^{12}$

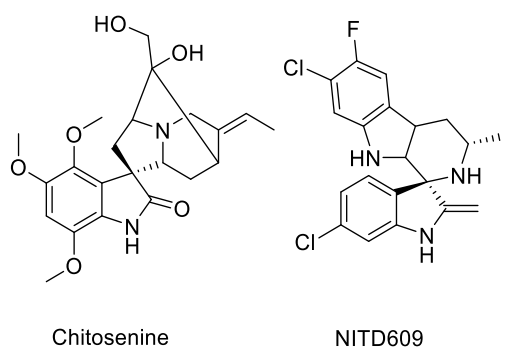

Figure 1. Biologically active natural products with a spiro oxindole scaffold.
For this reason, there have been numerous efforts towards the synthesis of heterocycles containing spiro oxindole as the core structure. ${ }^{13-18}$ Among different methodologies that have been developed for the synthesis of spiro molecules, ${ }^{19,20}$ the Michael addition is one of the most robust.21-24 Recently, the organocatalytic cascade Michael addition has emerged as an efficient strategy to provide spirocyclic oxindole structures in one-pot. ${ }^{25-29}$ For example, Wu et al. demonstrated a cascade [5+1] double-Michael addition between divinyl ketones and oxindoles $^{30}$ to afford spiro cyclohexanone oxindoles (scheme 1A). Later, Géant et al. applied tandem [5+1] double-Michael addition to obtaining spiro benzothiophenone cyclohexanone derivatives with high optical purity (Scheme 1B). ${ }^{31}$
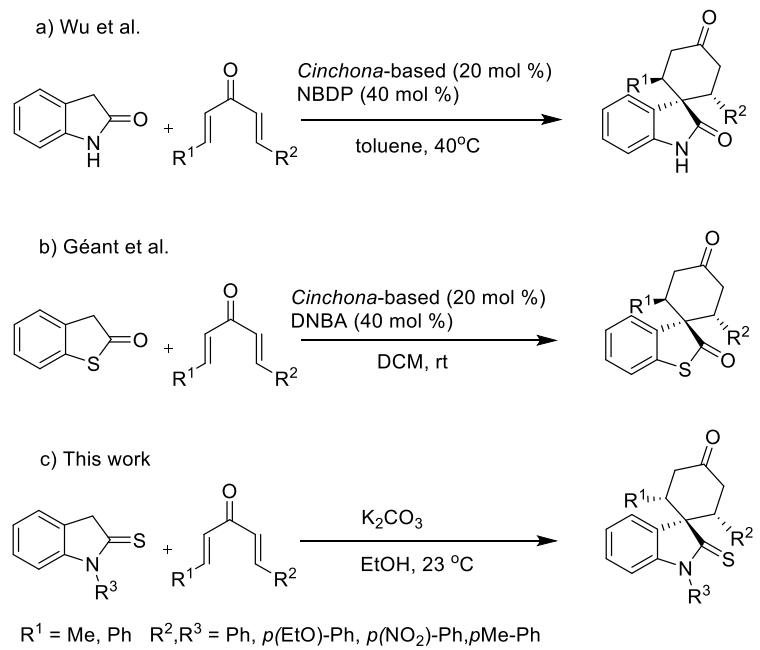

Scheme 1. Comparison of different cascade [5+1] double Michael additions of divinyl ketones.

However, despite all previous efforts in the synthesis of spiro oxindoles with trans $\mathrm{R}^{1}$ and $\mathrm{R}^{2}$ groups, the synthesis of cisspiro oxindoles has remained unexplored to the best of our knowledge. Since all previous biological studies have only focused on trans-spiro oxindoles, the cis isomer could be a demanding target for synthesis as it may further expand the biological activities of oxindoles. For example, Scala et al. discovered trans-spiro cyclohexanone oxindoles are efficient inhibitors that kill Leishmania infantum promastigotes and amastigotes without significant cytotoxic effects. ${ }^{32}$ More evidence for high activity of spiro oxindoles against leishmaniasis were confirmed later by Saha et al. ${ }^{33}$ The 
leishmaniases are a group of diseases caused by protozoan parasites from more than 20 Leishmania species. ${ }^{34} \mathrm{~A}$ better understanding of leishmaniasis was provided when French et al. demonstrated that L. donovani uridine 5'-monophosphate synthase (LdUMPS) is an essential enzyme for promastigotes viability and presented the crystal structure of the LdUMPS in complex with its product, UMP. ${ }^{35}$ Their structural analysis revealed a tetrameric structure for LdUMPD with two dimeric OMPDC and two dimeric OPRT functional domains. As a result of this unusual structure, the oligomerization of LdUMPS is controlled by ligand binding at the OPRT active site.

Regarding the structure-activity relationship, we hypothesized a cis-spiro (thio)oxindole might have a higher affinity towards the OPRT domain of LdUMPS than the trans isomer. To test this initial idea, we first performed some docking studies and then introduced a method to synthesize cis-spiro cyclohexanone thiooxindoles. In the next step and in continuation of our previous works on oxindole chemistry,36,37 we employed thiooxidole to react with divinyl ketones. The highly diastereoselective [5+1] double Michael addition resulted in cis-spiro cyclohexanone thiooxindoles, which could be later converted to cis-spiro cyclohexanone oxindoles. Finally, density functional theory (DFT) was used to explain the reaction regioselectivity and stereoselectivity.

\section{Result and discussion:}

Table 1. Calculated binding energies (kcal mol-1) of trans/cis-spiro (thio)oxindoles with OPRT domain of LdUMPS.

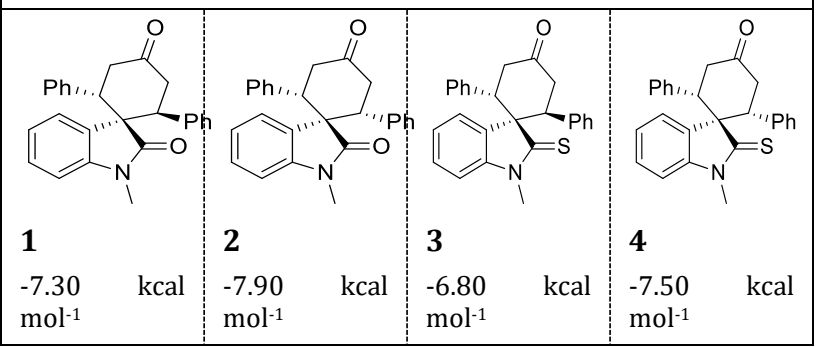

To gain an insight into the molecular determinants that can modulate the antagonistic activities of oxindole and thiooxindole, molecular docking studies were performed on cis and trans isomers. The results (Table 1), generated based on the crystal structure of the LdUMPS receptor, revealed that cis-spiro oxindole has the highest binding affinity towards LdUMPS active site. It binds to the OPRT domain of the LdUMPS receptor through interactions with Arg23, Phe54, Lys84, Asn138, Val175, Ser137, Pro199, Gln204, and Lys49 (figure 2, figure S1). The higher binding energy of cisspiro oxindole compared with the trans isomer relies on steric hindrance between trans-(thio)oxindole and the active site. It seems electronic factors are responsible for higher activity of trans-oxindole in comparison with transthiooxindole.

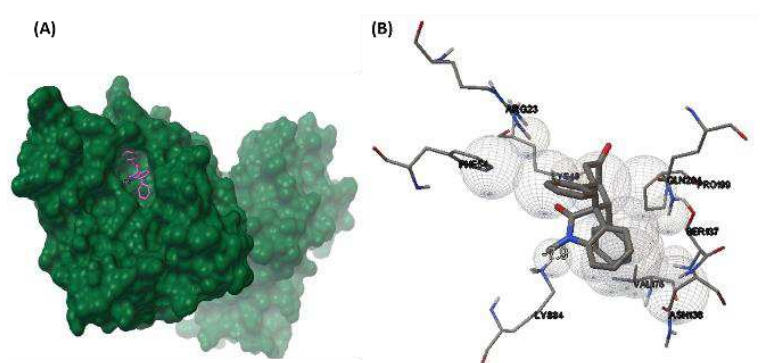

Figure 2. Interaction between cis-spiro oxindole 2 with (A) OPRT domain of the LdUMPS (PDB ID: 2WNS) and (B) residual amino acids of the active site; Arg23, Phe54, Lys84, Asn138, Val175, Ser137, Pro199, Gln204, and Lys49. 4b. The figure is drawn using UCSF chimera 1.8 and AutoDock version 1.5.6.38,39

Motivated by the initial docking results, which confirmed the importance of designing a robust synthetic method to provide cis-oxindole $\mathbf{2}$, we therefore commenced the synthesis design. Since all previously applied Michael reactions on oxindole have far resulted in the trans isomer $\mathbf{1}$ formation, it was hypothesized replacing the carbonyl group of the oxindole with a thiocarbonyl group may introduce an intramolecular repulsion between the large lone pair electrons of sulfur and aryl $\pi$ electrons. This could favor the formation of cis thiooxindole 4, which after one extra step can be converted to cis oxindole 2 . The hypothesis was confirmed by theoretical calculations. The DFT computations (figure 3) demonstrated due to the electronic repulsion; the cis isomer 4 is more thermodynamically stable than trans isomer $\mathbf{3}$ (table S1). These results also explain why previous works on oxindole, where the trans isomer $\mathbf{1}$ is more stable than $\mathbf{2}$, could only result in the trans isomer formation.
A

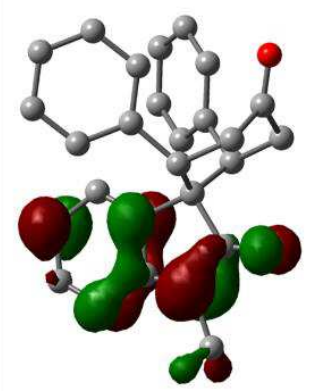

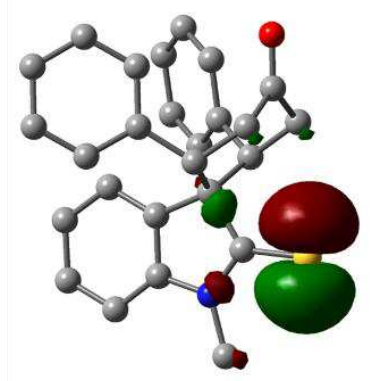

Figure 3. HOMO electronic cloud of (A) cis-spiro oxindole 2 and (B) cis-spiro thiooxindole 4. The diffusive electronic cloud around the sulfur atom in thiooxindole makes the cis isomer more stable than the trans isomer. DFT calculations were performed using B3LYP/6-31+G(d) in the gas phase.

In the next step, thiooxindole derivatives were generated from the reaction of oxindole with $\mathrm{P}_{2} \mathrm{~S}_{5}$ and sodium bicarbonate in dry THF. Dibenzal ketones were prepared through the condensation reaction of aldehyde and ketone in the presence of a suitable base and ethanol as the solvent. The [5+1] double Michel addition reaction was carried out on an equimolar mixture of freshly prepared thiooxindole $\mathbf{6}$ with divinyl ketone to provide single diastereoisomer 7 in high yield which was characterized through spectral analysis. The 
regio and diastereoselectivity of this reaction were established by the aim of the one- and two-dimensional NMR. In ${ }^{1} \mathrm{H}-\mathrm{NMR}$, compound 7 displayed two doublets at $\delta 6.55$ and $6.65 \mathrm{ppm}$, equivalent to 4 protons for each signal. This confirmed the $p$-ethoxyphenyl groups of the thiooxindole moiety exist at the cis position to each other. In the ${ }^{1} \mathrm{H}$ and ${ }^{13} \mathrm{C}$ NMR spectra, no signal was observed related to other diastereoisomers. Further analysis by COSY, NOESY, and single-crystal X-ray diffraction, revealed that the aryl groups stand toward the phenyl part of thiooxindole.

However, the high regioselectivity of this reaction was a surprise as one could expect to observe the Michael addition on alpha carbon and sulfur atoms which results in the formation of an eight-member ring. To explain the observed regioselectivity, we used DFT calculations. Looking at the charge distribution (figure 4), we noticed the alpha carbon of thiooxindole has a more negative charge than sulfur - even after the first addition - and thus can act as a better nucleophile. Furthermore, the alpha carbon of thiooxindole 6 has a more negative charge than the alpha carbon of oxindole 5. Accordingly, thiooxindole $\mathbf{6}$ is a better Michael donor than oxindole 5. This trend is in agreement with the strong resonance between $\mathrm{N}$ and $\mathrm{C}=\mathrm{O}$ in oxindole, whereas in thiooxindole there is a stronger resonance between the alpha carbon and $\mathrm{C}=\mathrm{S}$. Therefore, the charge distribution explains the formation of spiro structure over the eight-membered ring compounds.

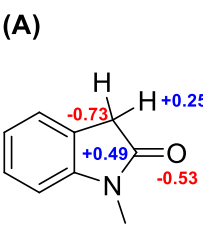

5
(B)

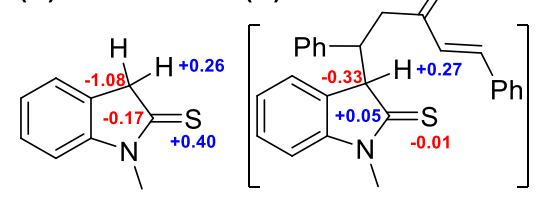

6
Figure 4. Mulliken charge distribution on (A) N-methyl oxindole 5, (B) N-methyl thiooxindole 6 and (C) the intermediate after the first Michael addition on N-methyl thiooxindole 6. Calculations were performed using B3LYP/6$31 \mathrm{G}(\mathrm{d})$ in the gas phase.

Table 2. Optimization of the double Michael addition reaction condition ${ }^{\mathrm{s}}$

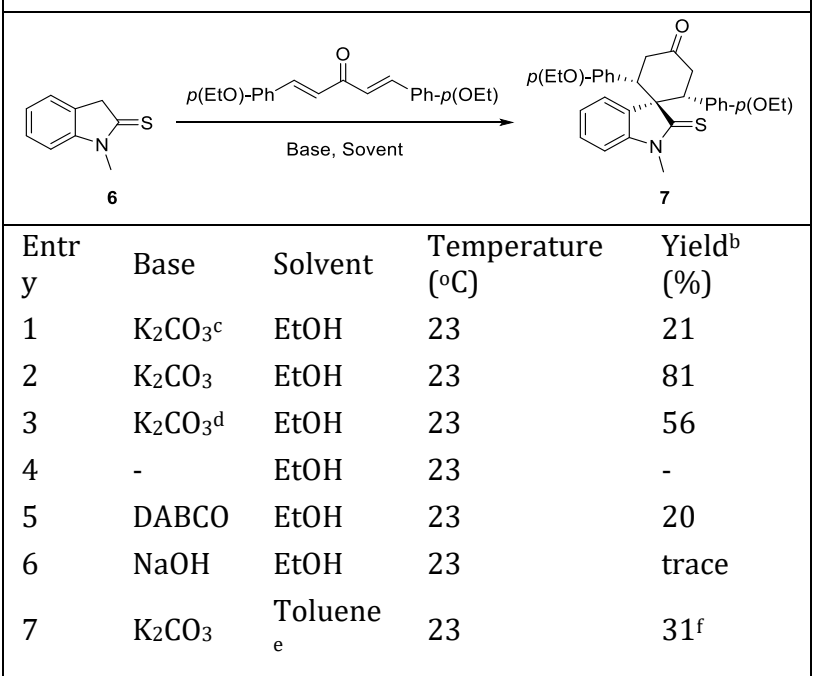

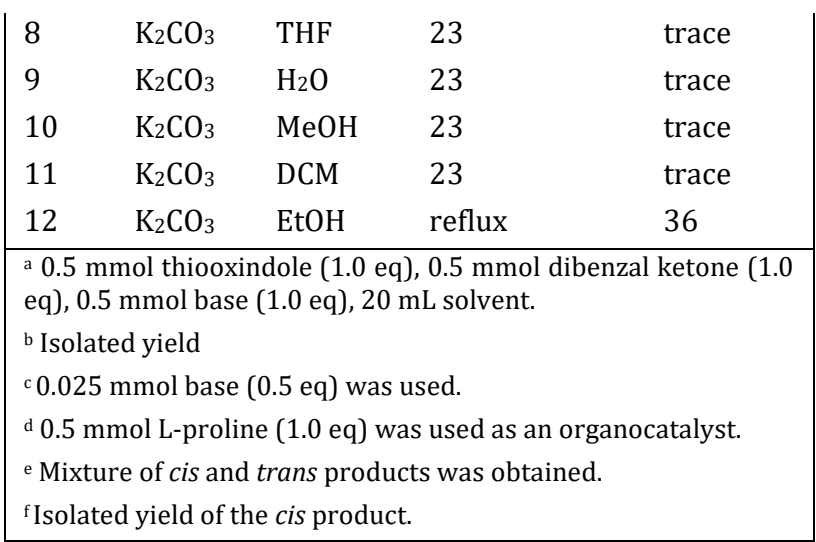

Delighted by these results, various optimization experiments were conducted to obtain the optimal reaction conditions using the reaction mentioned above as the model (table 2). The results showed $\mathrm{K}_{2} \mathrm{CO}_{3}$ accelerates the deprotonation step and thus promotes the reaction to proceed faster. The efficiency of this process could be further improved by increasing the amount of base up to $100 \mathrm{~mol} \%$. Exploring the effect of temperature showed that if the reaction was carried out in ethanol at the higher temperature (reflux), the yield of compound 7 would decrease. We also studied the effect of Lproline in the reaction, which resulted in a lower yield. Initially, it was expected L-proline would accelerate the reaction by forming dibenzal iminium intermediate. However, DFT calculations revealed the beta carbon of dibenzal iminium has less positive charge than the beta carbon of dibenzal ketone (figure S2), and thus the latter is a better Michael acceptor.

(A)

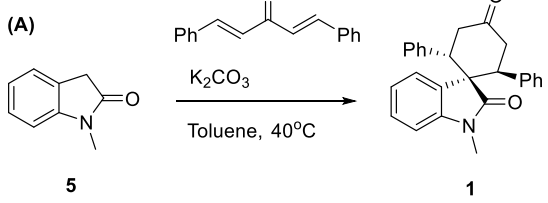

(B)
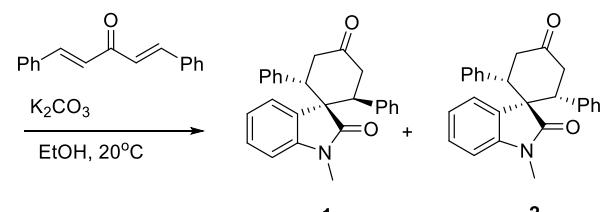

5

(C)<smiles>CN1C(=S)Cc2ccccc21</smiles>
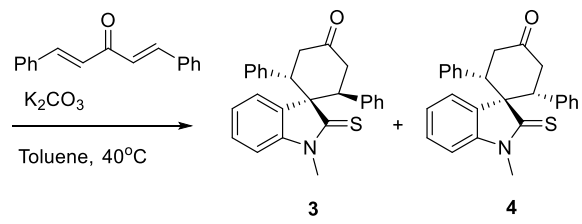

(D)<smiles>CN1C(=S)Cc2ccccc21</smiles>
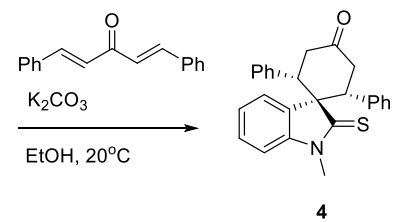

Scheme 2. Double Michael addition reaction of oxindole and thiooxindole on dibenzal ketones in ethanol and toluene. 
In the next step, the role of the solvent on the reaction was surveyed. Toluene has been previously used to convert oxindole 5 to trans-spiro cyclohexanone oxindole 1 (scheme $2 \mathrm{~A}$ ) as an aprotic and apolar solvent. The same reaction condition on thiooxindole 6 , resulted in a mixture of cis and trans spiro products 3 and $\mathbf{4}$ (Scheme 2B). We, therefore, introduced a method using ethanol as a polar and protic solvent that produces cis-spiro cyclohexanone thiooxindole 3 as a single diastereomer (Scheme 2D). It is worth mentioning that treating the oxindole $\mathbf{5}$ under our reaction condition ended with a mixture of cis and trans spiro cyclohexanone oxindole (scheme 2C). Therefore, we concluded both solvent and substrate electronic structure are involved in the determination of reaction diastereoselectivity. To better understand these effects, conductor-like polarizable continuum model (CPCM) ${ }^{40}$ was used in our DFT calculations. The theoretical results (figure S3) revealed trans configuration is more favorable in toluene, whereas the cis configuration can form easier in ethanol. This selectivity comes from the fact that the energy level of molecular orbitals and thus the repulsion between the chalcogen lone pair electrons and $\pi$ electrons of aryl groups depends on the polarity of the solvent. Thus, the double Michael addition on oxindole in ethanol and on thiooxindole in toluene resulted in selective formation of $\mathbf{1}$ and $\mathbf{4}$, respectively. However, when the reaction performed on oxindole in toluene and on thiooxindole in ethanol, the solvent and electronic effects became in conflict with each other, and a mixture of cis and trans isomers was obtained.

To further illustrate the scope of this reaction for the synthesis of complex heterocyclic spirothiooxindoles, $\mathrm{N}$ methylthiooxindole and N-phenylthiooxindole with dibenzal ketones bearing electron-donating or withdrawing group were used. The obtained results are summarized in Table 3. The reaction furnished spiro framework as a single diastereomer and in moderate to good yield in all cases. Furthermore, we successfully scaled up the process and isolated $>35 \mathrm{~g}$ of compound 7 with $66 \%$ yield.

Table 3. Double Michael addition of thiooxindole on dibenzal ketone, reaction yield, and binding energies (kcal mol-1) with OPRT domain of LdUMPS.

\begin{tabular}{|l|l|}
\hline \\
$Y$ Yield: $72 \%$
\end{tabular}

\begin{tabular}{|l|l|}
\hline \\
$Y i e l d: 69 \%$
\end{tabular}

The potential of synthesized compounds as inhibitors of LdUMPS was then recognized by molecular docking (table 3). Our study showed that $\mathbf{7}$ fits better into the active site of the receptor. $\mathrm{N}$-phenyl derivatives sterically intercut this fitting, and as a result, they have a lower binding affinity. Finally, we demonstrated it is possible to convert synthesized thiooxindoles into oxindole (scheme 3 ). Thus, our method opens a new window in the formation of biologically important cis-spiro oxindoles and cis-spiro thiooxindoles.

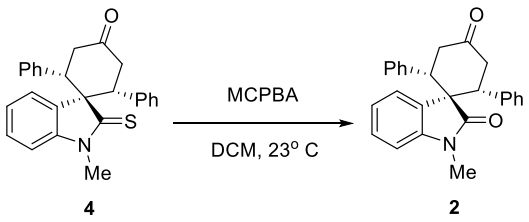

Scheme 3. Conversion of cis-spiro thiooxindole into cisspiro oxindole

\section{Conclusion:}

In summary, we have introduced a robust synthetic strategy for diastereomerically-pure spiro (thio)oxindole via double Michael addition of thiooxindoles on dibenzal ketones. The reaction furnished corresponding spiro products in only one diastereomer. The regioselectivity and stereoselectivity of the reaction were discussed in light of the computational results. Molecular docking studies were performed on the reaction products, which demonstrated high binding affinities towards the OPRT domain of the LdUMPS receptor. Our reported protocol is catalyst-free, scalable, has mild reaction conditions, and there is no need to work-up and column chromatography. These advantages make this method a suitable candidate for synthesizing complex heterocyclic spiro (thio)oxindole systems in synthetic and medicinal chemistry.

\section{ACKNOWLEDGMENT}

We thank Prof. Yvan Six for 2D NMR experiments and HRMS analysis and Marie Cordier for X-ray crystallography analysis. Financial support was provided by Sharif University of Technology, McGill University, and the Iran National Science Foundation grant to F.M.M for funding. 


\section{Experimental}

\section{General information}

All materials used are commercially available and were purchased from Merck and used without any additional purification. ${ }^{1} \mathrm{H}$ NMR, ${ }^{13} \mathrm{C}$ NMR, and 2-D NMR spectra were recorded on a Bruker (Avance DRX-500) spectrometer using $\mathrm{CDCl}_{3}$ or DMSO-d6 as solvent at room temperature. Chemical shifts $(\delta)$ are given in parts per million (ppm) and are reported relative to residual solvent peaks: $\mathrm{CDCl}_{3}(\delta \mathrm{H} 7.26$, $\delta \mathrm{C} 77.16 \mathrm{ppm})$, DMSO-d6 ( $\delta \mathrm{H} 2.50, \delta \mathrm{C} 39.52 \mathrm{ppm}$ ). Coupling constants (J) are given in Hertz (Hz). FTIR spectra of samples were taken using an ABB Bomem MB-100 FTIR spectrophotometer. HRMS analyses were performed using a TOF mass analyzer on Mat95XP-Trap apparatus. X-ray crystallography was carried out through APEX II CCD BRUKER detector.

\section{Computational studies}

In all calculations, B3LYP DFT functional theory ${ }^{41}$ and 6$31 \mathrm{G}(\mathrm{d})$ basis set ${ }^{42}$ was used. Calculations were performed in the gas phase or solution by CPCM model and at $298.15 \mathrm{~K}$. Conformer distribution was studied by Spartan, ${ }^{43}$ and Gaussian0944 was used for other calculations. The first frequency was utilized to assess whether structures were in the true optimized structure. The docking study was performed by using the Autodock 1.5.6. The size of the grid box was set to $20 \AA$. The enzyme structure was downloaded from the website protein data banks (PDB ID: 2WNS) and ligands optimized at 6-31G(d)-B3LYP level of theory by Gaussian. Auto Dock tools programs were used to visualize the complex in 3D. All single bonds of residue side chains inside the grid box were regarded as rotatable, and the docked ligand was allowed to rotate on all the single bonds and move flexibly within the grid box. The structural optimization was performed for 50,000 generations using a genetic algorithm.

\section{General procedure for the synthesis of dibenzalketone}

Preparation of dibenzal ketone from solid aldehyde: A mixture of $\mathrm{LiClO}_{4}(5 \mathrm{mmol}), \mathrm{Et}_{3} \mathrm{~N}(5 \mathrm{mmol})$, ketone (5 mmol), and aldehyde ( $5 \mathrm{mmol}$ ) in $20 \mathrm{~mL}$ ethanol as solvent was stirred at room temperature. TLC monitored reaction completion. After the completion of the reaction, the solvent was removed by rotatory evaporation at reduced pressure, and the residue was washed by ethanol to afford the pure product.

Preparation of dibenzal ketone from liquid aldehyde: A mixture of $\mathrm{NaOH}$ (25 mmol), ketone ( $5 \mathrm{mmol}$ ), and aldehyde ( $5 \mathrm{mmol}$ ) in the mixture of $\mathrm{H}_{2} \mathrm{O} / \mathrm{EtOH}(10: 8)$ was stirred at room temperature for 10 minutes. Again, ketone ( $5 \mathrm{mmol}$ ) and aldehyde ( $5 \mathrm{mmol}$ ) were added to the reaction mixture. TLC monitored reaction completion. After the completion of the reaction, the solvent was removed by rotatory evaporation at reduced pressure, and the residue was washed by ethanol to afford the pure product.

1,5-Diphenyl-penta-1,4-dien-3-one: Yellow solid, ${ }^{1} \mathrm{H}$ NMR $\left(\mathrm{CDCl}_{3}, 500\right.$ $\mathrm{MHz}), \delta 7.02(2 \mathrm{H}, \mathrm{d}, J=15.9 \mathrm{~Hz}), 7.42$

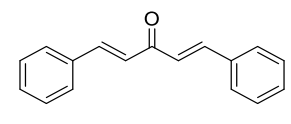

$(4 \mathrm{H}, \mathrm{dd}, J=5.0,1.8 \mathrm{~Hz}), 7.63(6 \mathrm{H}, \mathrm{dd}, J=6.4,3.1 \mathrm{~Hz}), 7.75(2 \mathrm{H}$, d, $J=15.9 \mathrm{~Hz}$ ). HRMS (ESI): $m / z 234.1051\left(\mathrm{M}^{+} \cdot \mathrm{C}_{17} \mathrm{H}_{14} \mathrm{O}^{+} \cdot\right.$ requires 234.1039). The spectroscopic data are consistent with those previously reported 45 .

1,5-Di-p-tolyl-penta-1,4-dien-3one: Yellow solid, ${ }^{1} \mathrm{H}$ NMR $\left(\mathrm{CDCl}_{3}\right.$, $500 \mathrm{MHz}), \delta 2.35(6 \mathrm{H}, \mathrm{s}), 7.09$

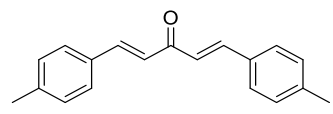
$(2 \mathrm{H}, \mathrm{d}, J=15.0 \mathrm{~Hz}), 7.29(4 \mathrm{H}, \mathrm{d}, J=7.5 \mathrm{~Hz}, 2 \mathrm{H}), 7.50(4 \mathrm{H}, \mathrm{d}, J$ $=7.5 \mathrm{~Hz}), 7.92(2 \mathrm{H}, \mathrm{d}, J=15.2 \mathrm{~Hz})$. HRMS (ESI): $m / z$ $262.1385\left(\mathrm{M}^{+} \cdot \mathrm{C}_{19} \mathrm{H}_{18} \mathrm{O}^{+\bullet}\right.$ requires 262.1352$)$. The spectroscopic data are consistent with those previously reported 45 .

\section{1,5-Bis-(4-ethoxy-phenyl)- penta-1,4-dien-3-one: Yellow solid, ${ }^{1} \mathrm{H}$ NMR $\left(\mathrm{CDCl}_{3}, 500\right.$ $\mathrm{MHz}), \delta 1.44(6 \mathrm{H}, \mathrm{t}, J=7.0$

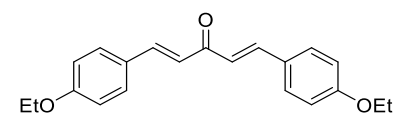 $\mathrm{Hz}), 4.08(4 \mathrm{H}, \mathrm{q}, J=7.0 \mathrm{~Hz}), 6.92(4 \mathrm{H}, \mathrm{d}, J=8.7 \mathrm{~Hz}), 6.95(2$ \\ $\mathrm{H}, \mathrm{d}, J=15.9 \mathrm{~Hz}), 7.56(4 \mathrm{H}, \mathrm{d}, J=8.7 \mathrm{~Hz}), 7.69(2 \mathrm{H}, \mathrm{d}, J=15.8$ $\mathrm{Hz}$ ). HRMS (ESI): $m / z 322.1574\left(\mathrm{M}^{+} \cdot \mathrm{C}_{21} \mathrm{H}_{22} \mathrm{O}_{3} \cdot \bullet\right.$ requires $322.1563)$. The spectroscopic data are consistent with those previously reported 45 .}

\section{1,5-Bis-(4-nitro-phenyl)- penta-1,4-dien-3-one: Brown solid, ${ }^{1} \mathrm{H}$ NMR (d6-DMSO,} $500 \mathrm{MHz}), \delta 7.56(2 \mathrm{H}, \mathrm{d}, J=$

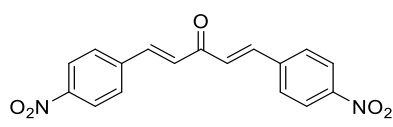
$16.1 \mathrm{~Hz}), 7.93(2 \mathrm{H}, \mathrm{d}, J=16.1 \mathrm{~Hz}), 8.08(4 \mathrm{H}, \mathrm{d}, J=8.5 \mathrm{~Hz})$, $8.31\left(4 \mathrm{H}, \mathrm{d}, J=8.5 \mathrm{~Hz}\right.$ ). HRMS (ESI): $m / z 324.0749\left(\mathrm{M}^{+} \cdot\right.$ $\mathrm{C}_{17} \mathrm{H}_{12} \mathrm{~N}_{2} \mathrm{O}_{5}+\bullet$ requires 324.0746$)$. The spectroscopic data are consistent with those previously reported 45 .

\section{General procedure for synthesizing thiooxindole}

An oven-dried flask was charged with oxindole (3.7 $\mathrm{mmol})$, dry THF $(25 \mathrm{~mL})$, and $\mathrm{P}_{2} \mathrm{~S}_{5}(2.3 \mathrm{mmol})$. The reaction mixture was stirred at room temperature for 10 minutes. Then, $\mathrm{NaHCO}_{3}$ (7.5 mmol) was slowly added and stirred overnight.

After removing the solvent by rotatory evaporation at reduced pressure, the residue was transferred into a $100-\mathrm{mL}$ beaker. By adding $250 \mathrm{~mL}$ mixture of ice and water, a pale yellow solid appeared. The light yellow precipitate was washed with $10 \%$ solution of $\mathrm{NaHCO}_{3}$ to remove unreacted oxindole and give the pure product.

1-methylindoline-2-thione (6): Yellow solid, ${ }^{1} \mathrm{H}$ $\mathrm{NMR}\left(\mathrm{CDCl}_{3}, 500 \mathrm{MHz}\right), \delta 7.32(1 \mathrm{H}, \mathrm{t}, J=7.8 \mathrm{~Hz})$,

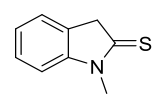
$7.27(1 \mathrm{H}, \mathrm{d}, J=7.8 \mathrm{~Hz}), 7.16(1 \mathrm{H}, \mathrm{t}, J=7.4 \mathrm{~Hz}), 6.98(1 \mathrm{H}, \mathrm{d}, J=$ $7.8 \mathrm{~Hz}$ ), 4.09 (s, 2H), 3.61 (s, 3H). HRMS (ESI): $m / z 163.0467$ $\left(\mathrm{M}^{+} \cdot \mathrm{C}_{9} \mathrm{H}_{9} \mathrm{NS}^{+} \cdot\right.$ requires 163.0450$)$. The spectroscopic data are consistent with those previously reported 46 .

1-phenylindoline-2-thione: brown solid, ${ }^{1} \mathrm{H}$ $\mathrm{NMR}\left(\mathrm{CDCl}_{3}, 500 \mathrm{MHz}\right), \delta 7.63(2 \mathrm{H}, \mathrm{t}, J=7.6 \mathrm{~Hz})$, $7.55(1 \mathrm{H}, \mathrm{t}, J=7.4 \mathrm{~Hz}), 7.43(2 \mathrm{H}, \mathrm{d}, J=7.5 \mathrm{~Hz})$, $7.38(1 \mathrm{H}, \mathrm{d}, J=7.15 \mathrm{~Hz}), 7.25(1 \mathrm{H}, \mathrm{t}, J=7.5 \mathrm{~Hz})$,

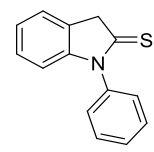
$7.20(1 \mathrm{H}, \mathrm{t}, J=7.32 \mathrm{~Hz}), 6.65(1 \mathrm{H}, \mathrm{d}, J=7.7 \mathrm{~Hz}), 4.32(2 \mathrm{H}, \mathrm{s})$. HRMS (ESI): $m / z \quad 225.0622 \quad\left(\mathrm{M}^{+\bullet} \mathrm{C}_{14} \mathrm{H}_{11} \mathrm{NS}^{+} \cdot\right.$ requires 225.0607). The spectroscopic data are consistent with those previously reported 47 .

General procedure for double Michael addition reaction

A mixture of thiooxindole $(0.5 \mathrm{mmol})$, divinyl ketone $(0.5$ $\mathrm{mmol})$, and $\mathrm{K}_{2} \mathrm{CO}_{3}(0.5 \mathrm{mmol})$ in $10 \mathrm{~mL}$ of ethanol was stirred at room temperature for about 24 hours. 
Reaction completion was monitored by TLC using mobile phase (ethyl acetate/hexane; 1:6). After the completion of the reaction, since the product is insoluble in ethanol and diethyl ether, the purification was done by washing the crude reaction mixture with these solvents.

(1s,2R,6S)-1'-methyl-2,6-diphenyl-2'-thioxospiro[cyclohexane1,3'-indolin]-4-one (4): White solid, ${ }^{1} \mathrm{H} \mathrm{NMR}\left(\mathrm{CDCl}_{3}, 500 \mathrm{MHz}\right)$, $\delta 2.82(2 \mathrm{H}, \mathrm{dd}, J=15.7,4.0 \mathrm{~Hz}), 3.00(3 \mathrm{H}, \mathrm{s}), 3.46(2 \mathrm{H}, \mathrm{t}, J=$ $15.1 \mathrm{~Hz}), 4.14(2 \mathrm{H}, \mathrm{dd}, J=14.6,4.2 \mathrm{~Hz}), 6.63(1 \mathrm{H}, \mathrm{d}, J=6.9 \mathrm{~Hz})$, $6.82(4 \mathrm{H}, \mathrm{d}, J=7.5 \mathrm{~Hz}), 6.95(4 \mathrm{H}, \mathrm{d}, J=7.7 \mathrm{~Hz}), 7.32-7.38(2 \mathrm{H}$, $\mathrm{m})$, 8.02-8.07 $(1 \mathrm{H}, \mathrm{m}) .{ }^{13} \mathrm{C} \mathrm{NMR}\left(\mathrm{CDCl}_{3}, 125.8 \mathrm{MHz}\right): \delta 34.6$, 43.7, 49.8, 67.6, 108.5, 125.5, 127.3, 127.5, 128.13, 128.5, 128.8, 129.5, 139.5, 146.9, 207.7, 208.5. HRMS (EI): $\mathrm{m} / \mathrm{z}$ $397.1480\left(\mathrm{M}^{+} \mathrm{C}_{26} \mathrm{H}_{23} \mathrm{NOS}^{+\bullet}\right.$ requires 397.1495).

\section{(1s,2R,6S)-2,6-bis(4-ethoxyphenyl)-1'-methyl-2'-}

thioxospiro[cyclohexane-1,3'-indolin]-4-one (7): White solid, ${ }^{1} \mathrm{H}$ NMR $\left(\mathrm{CDCl}_{3}, 500 \mathrm{MHz}\right), \delta 1.30(6 \mathrm{H}, \mathrm{t}, J=7.0 \mathrm{~Hz}), 2.75$ $(2 \mathrm{H}, \mathrm{dd}, J=15.6,3.9 \mathrm{~Hz}), 3.00(3 \mathrm{H}, \mathrm{s}), 3.39(2 \mathrm{H}, \mathrm{t}, J=15.1 \mathrm{~Hz})$, $3.85(4 \mathrm{H}, \mathrm{q}, J=7.0 \mathrm{~Hz}), 4.06(2 \mathrm{H}, \mathrm{dd}, J=14.3,2.7 \mathrm{~Hz}), 6.45(4$ $\mathrm{H}, \mathrm{d}, J=8.7 \mathrm{~Hz}), 6.64(1 \mathrm{H}, \mathrm{d}, J=6.9 \mathrm{~Hz}), 6.71(4 \mathrm{H}, \mathrm{d}, J=8.7 \mathrm{~Hz})$, $7.32(2 \mathrm{H}$, quin, $J=7.6 \mathrm{~Hz}), 7.99(1 \mathrm{H}, \mathrm{d}, J=7.3 \mathrm{~Hz}) .{ }^{13} \mathrm{C} \mathrm{NMR}$ $\left(\mathrm{CDCl}_{3}, 125.8 \mathrm{MHz}\right): \delta 14.7,31.1,45.0,51.2,63.1,68.1,110.0$, $113.3,123.2,125.3,128.8,129.5,129.7,132.6,146.2,157.8$, 204.7, 208.2. HRMS (EI): $m / z \quad 485.2015\left(\mathrm{M}^{+} \cdot \mathrm{C}_{30} \mathrm{H}_{31} \mathrm{NO}_{3} \mathrm{~S}^{+} \cdot\right.$ requires 485.2025 ).

\section{(1s,2R,6S)-1'-methyl-2'-thioxo-2,6-di- $p$ -}

tolylspiro[cyclohexane-1,3'-indolin]-4-one (8): White solid, ${ }^{1} \mathrm{H}$ NMR ( $\left.\mathrm{CDCl}_{3}, 500 \mathrm{MHz}\right), \delta 2.13(6 \mathrm{H}, \mathrm{s}), 2.77(2 \mathrm{H}, \mathrm{dd}, J=15.6$, $4.1 \mathrm{~Hz}), 2.98$ (3 H, s), 3.42 (2 H, t, $J=15.2 \mathrm{~Hz}), 4.09$ (2H, dd, $J$ $=14.5,4.2 \mathrm{~Hz}), 6.62(1 \mathrm{H}, \mathrm{d}, J=6.1 \mathrm{~Hz}), 6.68(4 \mathrm{H}, \mathrm{d}, J=8.0 \mathrm{~Hz})$, $6.74(4 \mathrm{H}, \mathrm{d}, J=7.9 \mathrm{~Hz}), 7.31-7.41(2 \mathrm{H}, \mathrm{m}), 8.01(1 \mathrm{H}, \mathrm{d}, J=7.2$ $\mathrm{Hz}) .{ }^{13} \mathrm{C} \mathrm{NMR}\left(\mathrm{CDCl}_{3}, 125.8 \mathrm{MHz}\right): \delta 20.8,31.0,44.9,51.7,67.8$, 110.0, 123.2, 125.3, 128.1, 128.3, 128.7, 132.5, 134.6, 136.6, 146.2, 204.5, 208.1. HRMS (EI): $m / z \quad 425.1796 \quad\left(\mathrm{M}^{+\bullet}\right.$ $\mathrm{C}_{28} \mathrm{H}_{27} \mathrm{NOS}^{+} \cdot$ requires 425.1813 ).

(1s,2R,6S)-1'-methyl-2,6-bis(4-nitrophenyl)-2'-

thioxospiro[cyclohexane-1,3'-indolin]-4-one (9): Brown solid,

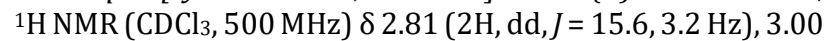
$(3 \mathrm{H}, \mathrm{s}), 3.47(2 \mathrm{H}, \mathrm{t}, J=15.2 \mathrm{~Hz}), 4.13(2 \mathrm{H}, \mathrm{dd}, J=14.5,3.5 \mathrm{~Hz})$, $6.76(1 \mathrm{H}, \mathrm{d}, \mathrm{J}=6.3 \mathrm{~Hz}), 7.59-7.58(2 \mathrm{H}, \mathrm{m}), 7.68(4 \mathrm{H}, \mathrm{d}, J=8.5$ $\mathrm{Hz}), 7.91(4 \mathrm{H}, \mathrm{d}, J=8.5 \mathrm{~Hz}) 8.16(1 \mathrm{H}, \mathrm{dd}, J=4.9,1.9 \mathrm{~Hz}) \cdot{ }^{13} \mathrm{C}$ NMR $\left(\mathrm{CDCl}_{3}, 125.8 \mathrm{MHz}\right): \delta 34.6,43.7,49.8,67.6,108.5,123.3$, 125.5, 127.3, 128.5, 128.6, 129.5, 146.0 146.9, 149.0, 207.7, 208.5. HRMS (EI): $m / z 487.1187\left(\mathrm{M}^{+} \cdot \mathrm{C}_{26} \mathrm{H}_{21} \mathrm{~N}_{3} \mathrm{O}_{5} \mathrm{~S}^{+\bullet}\right.$ requires 487.1202).

(1s,2R,6S)-1',2,6-triphenyl-2'-thioxospiro[cyclohexane-1,3'indolin]-4-one (10): White solid, ${ }^{1} \mathrm{H} \mathrm{NMR}\left(\mathrm{CDCl}_{3}, 500 \mathrm{MHz}\right), \delta$ $2.85(2 \mathrm{H}, \mathrm{d}, J=14.5 \mathrm{~Hz}), 3.50(2 \mathrm{H}, \mathrm{t}, J=15.0 \mathrm{~Hz}), 4.16(2 \mathrm{H}, \mathrm{d}$, $J=14.1 \mathrm{~Hz}), 6.20(3 \mathrm{H}, \mathrm{s}), 7.32(8 \mathrm{H}, \mathrm{s}), 7.53-7.56(11 \mathrm{H}, \mathrm{m}), 8.06$ $(1 \mathrm{H}, \mathrm{d}, J=7.3 \mathrm{~Hz}) .{ }^{13} \mathrm{C} \mathrm{NMR}\left(\mathrm{CDCl}_{3}\right.$ and d6-DMSO, $\left.125.8 \mathrm{MHz}\right)$ : $\delta 43.3,50.5,66.6,109.5,112.5,122.3,125.8,126.7,127.3$, 127.4, 127.4, 128.3, 130.6, 133.3, 135.1, 135.3, 145.6, 204.4, 208.4. HRMS (EI): $m / z 459.1553\left(\mathrm{M}^{+} \cdot \mathrm{C}_{31} \mathrm{H}_{25} \mathrm{NOS}^{+} \bullet\right.$ requires 459.1657).

(1s,2R,6S)-2,6-bis(4-ethoxyphenyl)-1'-phenyl-2'-

thioxospiro[cyclohexane-1,3'-indolin]-4-one (11): White solid, ${ }^{1} \mathrm{H} \mathrm{NMR}\left(\mathrm{CDCl}_{3}, 500 \mathrm{MHz}\right), \delta 1.34(6 \mathrm{H}, \mathrm{s}), 2.83$ (2 H, d, J 14.7), $3.48(2 \mathrm{H}, \mathrm{t}, J=15.0), 3.91(4 \mathrm{H}, \mathrm{s}), 4.14(2 \mathrm{H}, \mathrm{d}, J=13.3), 6.19$ $(1 \mathrm{H}, \mathrm{d}), 6.28(2 \mathrm{H}, \mathrm{s}), 6.54(4 \mathrm{H}, \mathrm{d}, J=7.6), 6.81(4 \mathrm{H}, \mathrm{d}, J=7.4)$,
$7.21(1 \mathrm{H}, \mathrm{t}), 7.33(4 \mathrm{H}, \mathrm{s}), 8.04(1 \mathrm{H}, \mathrm{d}, J=6.6) .{ }^{13} \mathrm{C} \mathrm{NMR}\left(\mathrm{CDCl}_{3}\right.$, $125.8 \mathrm{MHz}$ ): $\delta 13.5,43.5,50.0,61.8,67.0,109.5,112.0,122.4$, $124.6,125.9,127.5,127.7,128.3,128.4,128.5,130.7,135.1$, 145.6, 156.7, 204.7, 208.6. HRMS (EI): $m / z$ 547.2187 (M+• $\mathrm{C}_{35} \mathrm{H}_{33} \mathrm{NO}_{3} \mathrm{~S}^{+\bullet}$ requires 547.2176).

(1s,2R,6S)-1'-phenyl-2'-thioxo-2,6-di-p-tolylspiro[cyclohexane1,3'-indolin]-4-one (12): White solid, ${ }^{1} \mathrm{H}$ NMR $\left(\mathrm{CDCl}_{3}, 500\right.$ $\mathrm{MHz}), \delta 2.23(6 \mathrm{H}, \mathrm{s}), 2.88(2 \mathrm{H}, \mathrm{d}, J=14.5 \mathrm{~Hz}), 3.53(2 \mathrm{H}, \mathrm{t}, J=$ $14.7 \mathrm{~Hz}), 4.18(2 \mathrm{H}, \mathrm{d}, J=14.2 \mathrm{~Hz}), 6.23(3 \mathrm{H}, \mathrm{s}), 6.83(8 \mathrm{H}, \mathrm{dd}, J$ $=25.0 \mathrm{~Hz}), 7.34(5 \mathrm{H}, \mathrm{m}), 8.08(1 \mathrm{H}, \mathrm{d}, J=7.2 \mathrm{~Hz}) .{ }^{13} \mathrm{C} \mathrm{NMR}$ ( $\mathrm{CDCl}_{3}$ and d6-DMSO, $\left.125.8 \mathrm{MHz}\right): \delta 20.3,44.0,51.2,67.3$, $110.2,113.2,123.0,126.5,127.1,128.0,128.1,128.3129 .0$, 134.0, 135.8, 136.0, 146.4, 205.2, 207.1. HRMS (EI): $\mathrm{m} / \mathrm{z}$ $487.1959\left(\mathrm{M}^{+} \cdot \mathrm{C}_{35} \mathrm{H}_{33} \mathrm{NO}_{3} \mathrm{~S}^{+\bullet}\right.$ requires 487.1970$)$.

(1s,2R,6S)-2,6-bis(4-nitrophenyl)-1'-phenyl-2'-

thioxospiro[cyclohexane-1,3'-indolin]-4-one (13): Brown solid, ${ }^{1} \mathrm{H}$ NMR $\left(\mathrm{CDCl}_{3}, 500 \mathrm{MHz}\right) \delta 2.95(2 \mathrm{H}, \mathrm{dd}, J=15.5,3.2$ $\mathrm{Hz}), 3.60(2 \mathrm{H}, \mathrm{t}, J=15.3 \mathrm{~Hz}), 4.26(2 \mathrm{H}, \mathrm{dd}, J=14.5,3.3 \mathrm{~Hz})$, $6.72(3 \mathrm{H}, \mathrm{s}), 7.78-7.89(5 \mathrm{H}, \mathrm{m}), 7.98(4 \mathrm{H}, \mathrm{d}, J=8.5 \mathrm{~Hz}), 8.01$ $(4 \mathrm{H}, \mathrm{d}, J=8.5 \mathrm{~Hz}) 8.15(1 \mathrm{H}, \mathrm{dd}, J=4.4,1.7 \mathrm{~Hz}) .{ }^{13} \mathrm{C} \mathrm{NMR}\left(\mathrm{CDCl}_{3}\right.$, $125.8 \mathrm{MHz}$ ): $\delta$ 43.7, 49.8, 67.3, 112.7, 123.3, 125.4, 126.4, $127.4,128.2,128.6,128.6,129.1,131.3,139.4,142.6,146.0$ 149.0, 207.0, 208.5. HRMS (EI): $m / z \quad 549.1361 \quad\left(\mathrm{M}^{+}\right.$ $\mathrm{C}_{31} \mathrm{H}_{23} \mathrm{~N}_{3} \mathrm{O}_{5} \mathrm{~S}^{+} \cdot$ requires 549.1358$)$.

\section{REFERENCES}

1. Bassyouni, F. H., M. E.; Rashed, A. E.; Rehim, M. A. , Molecular Modeling and Biological Activities of New Potent Antimicrobial, AntiInflammatory and Anti-Nociceptive of 5-Nitro Indoline-2-One Derivatives. Derivatives Drug Designing: Open Access 2017, 6 (2).

2. Brahmachari, G.; Banerjee, B., Facile and One-Pot Access of 3,3Bis(indol-3-yl)indolin-2-ones and 2,2-Bis(indol-3-yl)acenaphthylen$1(2 \mathrm{H})$-one Derivatives via an Eco-Friendly Pseudo-Multicomponent Reaction at Room Temperature Using Sulfamic Acid as an OrganoCatalyst. ACS Sustainable Chemistry \& Engineering 2014, 2 (12), 2802-2812.

3. Venkatesan, H.; Davis, M. C.; Altas, Y.; Snyder, J. P.; Liotta, D. C., Total Synthesis of SR 121463 A, a Highly Potent and Selective Vasopressin V2 Receptor Antagonist. J Org Chem 2001, 66 (11), 3653-3661.

4. Sakai, S.; Aimi, N.; Yamaguchi, K.; Ohhira, H.; Hori, K.; Haginiwa, J., Gardneria alkaloids -IX structures of chitosenine and three other minor bases: From Gardneria multiflora makino. Tetrahedron Lett 1975, 16 (10), 715-718.

5. Sakai, S.-i.; Aimi, N.; Yamaguchi, K.; Yamanaka, E.; Haginiwa, J., Gardneria alkaloids. Part 13. Structure of gardmultine and demethoxygardmultine; bis-type indole alkaloids of Gardneria multiflora Makino. J Chem Soc, Perkin Trans 1 1982, (0), 1257-1262.

6. Rottmann, M.; McNamara, C.; Yeung, B. K. S.; Lee, M. C. S.; Zou, B.; Russell, B.; Seitz, P.; Plouffe, D. M.; Dharia, N. V.; Tan, J.; Cohen, S. B.; Spencer, K. R.; González-Páez, G. E.; Lakshminarayana, S. B.; Goh, A.; Suwanarusk, R.; Jegla, T.; Schmitt, E. K.; Beck, H.-P.; Brun, R.; Nosten, F.; Renia, L.; Dartois, V.; Keller, T. H.; Fidock, D. A.; Winzeler, E. A.; Diagana, T. T., Spiroindolones, a potent compound class for the treatment of malaria. Science (New York, NY) 2010, 329 (5996), 1175-1180.

7. Dideberg, O.; Lamotte-Brasseur, J.; Dupont, L.; Campsteyn, H.; Vermeire, M.; Angenot, L., Structure cristalline et moléculaire d'un nouvel alcalöide bisindolique: complexe moléculaire 1:2 strychnofoline-ethanol (C30H34N402.2C2H6O). 1977, 33 (6), 17961801. 
8. Subramaniam, G.; Hiraku, O.; Hayashi, M.; Koyano, T.; Komiyama, K.; Kam, T.-S., Biologically Active Aspidofractinine, Rhazinilam, Akuammiline, and Vincorine Alkaloids from Kopsia. J Nat Prod 2007, 70 (11), 1783-1789.

9. Janin, Y. L., Antituberculosis drugs: Ten years of research. Biorg Med Chem 2007, 15 (7), 2479-2513.

10. Gutierrez-Lugo, M.-T.; Bewley, C. A., Natural Products, Small Molecules, and Genetics in Tuberculosis Drug Development. J Med Chem 2008, 51 (9), 2606-2612.

11. Zea, A.; Alba, A.-N. R.; Mazzanti, A.; Moyano, A.; Rios, R., Highly enantioselective cascade synthesis of spiropyrazolones. Organic \&amp; biomolecular chemistry 2011, 9 (19), 6519-6523.

12. Zhu, C.-L.; Zhang, F.-G.; Meng, W.; Nie, J.; Cahard, D.; Ma, J.-A., Enantioselective Base-Free Electrophilic Amination of Benzofuran2(3H)-ones: Catalysis by Binol-Derived P-Spiro Quaternary Phosphonium Salts. Angew Chem Int Ed 2011, 50 (26), 5869-5872.

13. Bondock, S.; Rabie, R.; Etman, H. A.; Fadda, A. A., Synthesis and antimicrobial activity of some new heterocycles incorporating antipyrine moiety. Eur J Med Chem 2008, 43 (10), 2122-2129.

14. Wan, J.-P.; Lin, Y.; Huang, Q.; Liu, Y., Diastereoselective Construction of Tetrahydropyridine Fused Bicyclic Structures via Three-Component Domino Reaction.J Org Chem 2014, 79 (15), 72327238.

15. Chen, X.-B.; Liu, Z.-C.; Yang, L.-F.; Yan, S.-J.; Lin, J., A ThreeComponent Catalyst-Free Approach to Regioselective Synthesis of Dual Highly Functionalized Fused Pyrrole Derivatives in WaterEthanol Media: Thermodynamics versus Kinetics. ACS Sustainable Chemistry \& Engineering 2014, 2 (5), 1155-1163.

16. Song, Z.; Huang, X.; Yi, W.; Zhang, W., One-Pot Reactions for Modular Synthesis of Polysubstituted and Fused Pyridines. Org Lett 2016, 18 (21), 5640-5643

17. Mancebo-Aracil, J.; Nájera, C.; Sansano, J. M., Multicomponent synthesis of unnatural pyrrolizidines using 1,3-dipolar cycloaddition of proline esters. Chemical Communications 2013, 49 (95), 1121811220.

18. Zhang, X., Legris, M., Muthengi, A., Zhang, W. , [3+2] CYCLOADDITION-BASED ONE-POT SYNTHESIS OF 3,9 DIAZABICYCLO[4.2.1]NONANE-CONTAINING SCAFFOLD. Chemistry of Heterocyclic Compounds 2017, 53 (4), 468-473.

19. Selva, V.; Larrañaga, O.; Castelló, L. M.; Nájera, C.; Sansano, J. M.; de Cózar, A., Diastereoselective [3 + 2] vs [4+2] Cycloadditions of Nitroprolinates with $\alpha, \beta$-Unsaturated Aldehydes and Electrophilic Alkenes: An Example of Total Periselectivity. J Org Chem 2017, 82 (12), 6298-6312.

20. Zhang, X.; Qiu, W.; Ma, X.; Evans, J.; Kaur, M.; Jasinski, J. P.; Zhang, W., One-Pot Double [3 + 2] Cycloadditions for Diastereoselective Synthesis of Pyrrolidine-Based Polycyclic Systems. J Org Chem 2018 83 (21), 13536-13542.

21. Yamazaki, T.; Shinohara, N.; Kitazume, T.; Sato, S., Highly Diastereoselective Sequential Enolate-Michael Addition-Ireland Claisen Rearrangement. J Org Chem 1995, 60 (25), 8140-8141.

22. Srivastava, N.; Banik, B. K., Bismuth Nitrate-Catalyzed Versatile Michael Reactions. J Org Chem 2003, 68 (6), 2109-2114.

23. Krause, N.; Hoffmann-Röder, A., Recent Advances in Catalytic Enantioselective Michael Additions. Synthesis 2001, 2001 (02), 0171 0196.
24. Okino, T.; Hoashi, Y.; Takemoto, Y., Enantioselective Michael Reaction of Malonates to Nitroolefins Catalyzed by Bifunctional Organocatalysts. J Am Chem Soc 2003, 125 (42), 12672-12673.

25. Sivasankara, C.; Satham, L.; Namboothiri, I. N. N., One-Pot Construction of Functionalized Spiro-dihydronaphthoquinoneoxindoles via Hauser-Kraus Annulation of Sulfonylphthalide with 3Alkylideneoxindoles. J Org Chem 2017, 82 (23), 12939-12944.

26. Wang, L.-L.; Peng, L.; Bai, J.-F.; Huang, Q.-C.; Xu, X.-Y.; Wang, L.-X., Highly organocatalytic asymmetric Michael-ketone aldoldehydration domino reaction: straightforward approach to construct six-membered spirocyclic oxindoles. Chemical Communications 2010, 46 (42), 8064-8066.

27. Ball-Jones, N. R.; Badillo, J. J.; Franz, A. K., Strategies for the enantioselective synthesis of spirooxindoles. Org Biomol Chem 2012, 10 (27), 5165-5181.

28. Cheng, D.; Ishihara, Y.; Tan, B.; Barbas, C. F., Organocatalytic Asymmetric Assembly Reactions: Synthesis of Spirooxindoles via Organocascade Strategies. ACS Catalysis 2014, 4 (3), 743-762.

29. Li, Z.; Li, J.; Yang, J., Chemoselective Double Michael Addition: Synthesis of 2,6-Diarylspiro[Cyclohexane-1,3'-Indoline]-2',4-Diones via Addition of Indolin-2-One to Divinyl Ketones. Journal of Chemical Research 2017, 41 (3), 168-171.

30. Wu, B.; Chen, J.; Li, M.-Q.; Zhang, J.-X.; Xu, X.-P.; Ji, S.-J.; Wang, X.W., Highly Enantioselective Synthesis of Spiro[cyclohexanoneoxindoles] and Spiro[cyclohexanone-pyrazolones] by Asymmetric Cascade [5+1] Double Michael Reactions. European J Org Chem 2012, 2012 (7), 1318-1327.

31. Géant, P.-Y.; Urban, M.; Remeš, M.; Císařová, I.; Veselý, J., Enantioselective Organocatalytic Synthesis of Sulfur-Containing Spirocyclic Compounds. European J Org Chem 2013, 2013 (35), 79797988.

32. Scala, A.; Cordaro, M.; Grassi, G.; Piperno, A.; Barberi, G.; Cascio, A.; Risitano, F., Direct synthesis of C3-mono-functionalized oxindoles from $\mathrm{N}$-unprotected 2-oxindole and their antileishmanial activity. Biorg Med Chem 2014, 22 (3), 1063-1069.

33. Saha, S.; Acharya, C.; Pal, U.; Roy Chowdhury, S.; Sarkar, K.; Maiti, N. C.; Jaisankar, P.; Majumder, H. K., A novel spirooxindole derivative inhibits the growth of \&lt;em\&gt;Leishmania donovani\&lt;/em\&gt; parasite both \&lt;em\&gt;in vitro\&lt;/em\&gt; and \&lt;em\&gt;in vivo\&lt;/em\&gt; by targeting type IB topoisomerase. Antimicrob Agents Chemother 2016, AAC.00352-16.

34. Pulvertaft, R. J. V.; Hoyle, G. F., Stages in the life-cycle of Leishmania donovani. Trans R Soc Trop Med Hyg 1960, 54 (2), 191196.

35. French, J. B.; Yates, P. A.; Soysa, D. R.; Boitz, J. M.; Carter, N. S.; Chang, B.; Ullman, B.; Ealick, S. E., The Leishmania donovani UMP Synthase Is Essential for Promastigote Viability and Has an Unusual Tetrameric Structure That Exhibits Substrate-controlled Oligomerization. J Biol Chem 2011, 286 (23), 20930-20941.

36. Moghaddam, F. M.; Khodabakhshi, M. R.; Kiamehr, M.; Ghahremannejad, Z., Synthesis of novel pentacyclic thiopyrano indole-annulated benzo- $\delta$-sultone derivatives via a domino Knoevenagel-hetero-Diels-Alder reaction in water. Tetrahedron Lett 2013, 54 (21), 2685-2689.

37. Moghaddam, F. M.; Saeidian, H.; Mirjafary, Z.; Taheri, S.; Kheirjou, S., A New and Facile Synthesis of Thieno[2,3-b]indole Derivatives via Condensation of Isocyanide and Indolin-2-thiones. Synlett 2009, 2009 (07), 1047-1050.

38. Pettersen, E. F.; Goddard, T. D.; Huang, C. C.; Couch, G. S.; Greenblatt, D. M.; Meng, E. C.; Ferrin, T. E., UCSF Chimera--a 
visualization system for exploratory research and analysis. J Comput Chem 2004, 25 (13), 1605-12.

39. Sanner, M. F., Python: a programming language for software integration and development. J Mol Graph Model 1999, 17 (1), 57-61.

40. Cossi, M.; Barone, V., Time-dependent density functional theory for molecules in liquid solutions. J Chem Phys 2001, 115 (10), 47084717.

41. Zhao, Y.; Schultz, N. E.; Truhlar, D. G., Exchange-correlation functional with broad accuracy for metallic and nonmetallic compounds, kinetics, and noncovalent interactions. J Chem Phys 2005, 123 (16), 161103

42. Hariharan, P. C.; Pople, J. A., The influence of polarization functions on molecular orbital hydrogenation energies. Theor Chim Acta 1973, 28 (3), 213-222.

43. W. Hehre, J. Y., P. Klunzinger, L. Lou, Wavefunction Inc. Irvine, CA 2008.

44. Frisch, M. J., Gaussian, Inc. Wallingford, CT 2010.

45. Kondhare, D.; Deshmukh, S.; Lade, H. Processes 2019, 7, 417.

46. Mane, V.; Baiju, T. V. ; Namboothiri, N, N; ACS Omega 2018, 3, 12 17617-17628.

47.Matloubi Moghaddam, M; Mirjafary, M., Saeidian, M.; Taheri S.; Doulabi, M.; Kiamehr, M; Tetrahedron 2010, 66, 134-138.

\section{Author information}

Affiliations

Laboratory of Organic Synthesis and Natural Products, Department of Chemistry, Sharif University of Technology, 111559516 Tehran, Iran

Firouz Matloubi Moghaddam, Vahid Saberi

Department of Chemistry, McGill University, H3A-0B8 Montreal, Canada

Ashkan Karimi

Contributions

F.M.M. is a professor in organic chemistry at SUT. He devised the project and the main conceptual ideas and was in charge of overall direction and planning. V.S. is a Ph.D candidate in organic chemistry at SUT. He performed the experiments, analyzed spectra, and wrote the original draft. A.K. is a former MSc student at SUT and now Ph.D candidate in organic chemistry at McGill University. He contributed to perform experiments and docking studies. All authors reviewed the manuscript

Corresponding author

Correspondence to Firouz Matloubi Moghaddam. 


\section{Supplementary Files}

This is a list of supplementary files associated with this preprint. Click to download.

- supportinginformation7.docx 